\title{
Integrating crime prevention into urban design and planning
}

\author{
Dr Caroline L. Davey \& Andrew B. Wootton \\ Design Against Crime Solution Centre \\ University of Salford, UK
}

\begin{abstract}
Purpose: This paper aims to understand the delivery of Crime Prevention Through Environmental Design (CPTED) across Europe-from European-wide procedures, through national schemes to effective local strategies.
\end{abstract}

Methodology: The findings come from a review of published literature and reports, case studies and site visits conducted primarily during COST Action TU1203 (2013-16).

Findings: Innovative approaches and methods to integrate crime prevention into urban design, planning and management have been generated by multi-agency partnerships and collaborations at European, national and city levels. Methods and procedures developed by the European Committee for Standardization (CEN) Working Group on "Crime Prevention through Urban Planning and Building Design" are pioneering. However, findings show that implementation is best achieved at a local level using methods and procedures tailored to the specific context.

Practical and research implications: In-depth research is required to appreciate subtle differences between local approaches and conceptual models developed to better understand approaches and methods. In addition, practitioners and academics working to prevent crime benefit from participation in focused, multi-agency collaborations that, importantly, facilitate visits to urban developments, discussions with local stakeholders responsible for delivery 'on the ground' and structured and sustained exploration of innovations and challenges.

Originality / value: The authors hope that this paper will contribute to developing a new direction for CPTED practice and research that builds on significant progress in creating safer environments over previous decades.

Keywords: Crime Prevention; Urban design and planning; Urban management; European standard; Delivery; Capability maturity; Professionalisation

\subsection{Introduction}

The European Union has for decades supported the development and implementation of Crime Prevention through Environmental Design (CPTED) across Europe. CPTED approaches intervene to reduce opportunities for offending behaviour in urban contexts by making crimes harder to commit, less rewarding, etc., helping to reduce victimisation across Europe (van Dijk, et al, 2012; van Dijk, 2013). In the late 1990s, the European Committee for Standardization (CEN) set up an international working group to establish criteria on "Crime Prevention through Urban Planning and Building Design". However, efforts to implement a standardised approach to CPTED delivery across Europe have not been successful (Stummvoll, 2013). 
The aim of this paper is to identify and review the approaches to CPTED that have been adopted across Europe - from the universal approach advocated within the European Standard, through national schemes to innovative local examples. The authors describe not only the origins, development and implementation of the different approaches (Cozens and Love, 2015), but also the extent to which the different approaches embed crime prevention within urban design practice-i.e. the process of shaping cities, towns and villages that involves the design of buildings, areas, spaces and landscapes to meet defined requirements (www.udg.org.uk/careers). A full review of the theory is provided by Schubert of the scope of this paper, but key terms and developments are briefly described.

\subsection{Background to the literature and key terms}

The last few decades have seen a shift towards 'prevention' and the emergence of a variety of crime prevention practices (Clancey et al, 2011). A significant number of preventative approaches focus on reducing 'opportunities' for crime. Increased crime in the 1960s and 1970 s has been attributed to societal changes creating opportunities for crime (Cohen and Felson, 1979). In dual income families, homes vacated during the day became targets for burglary, while the growth of portable consumer goods provided opportunities for theft and robbery (Clarke, 1999).

While opportunities for crime foster and enable offending behaviour, evidence from analyses of international victimisation data reveal that opportunities-and thus offending —can be reduced through better design, planning, management and security (Farrell, 2013; van Dijk et al, 2012; van Dijk, 2013). Crime prevention approaches founded on opportunity theory include Crime Prevention Through Environmental Design (CPTED), Situational Crime Prevention (SCP) and Crime Prevention Through Urban Design and Planning (CP-UDP) (Ekblom, 2001; Schneider and Kitchen, 2002).

CPTED is one of the most commonly used terms (Cozens and Love, 2015). Its origins are attributed to Jane Jacobs (1961), C. Ray Jeffery (1971) and Oscar Newman (1972). In The Death and Life of Great American Cities, Jacobs identified the importance of feelings of personal safety to a well-functioning city. Jacobs-a journalist- challenged American planning approaches, arguing that practitioners and theorists should examine "how cities are in real life... to learn what principles of planning and what practices in rebuilding can promote social and economic vitality in cities" (ibid). An architect, Newman (1972) developed design concepts and features to help create safer urban environments-'defensible space' being the most widely adopted. Other CPTED principles to deter potential offenders include: access control, surveillance, territoriality and urban management (Cozens and Love, 2015; Ekblom, $2009,2011)$. For an extensive discussion of the theoretical framework of CPTED and CPUPD s. Schubert [AK2] (2016 this issue).

CPTED is criticised for focusing on security-style solutions that 'target harden' premises and for neglecting 'softer' or human-centred solutions. There is also concern that some key terms (such as 'defensible space', 'natural surveillance' and 'symbolic barriers') are used by crime prevention experts as though they are proven techniques that can be applied to all contexts (Shaftoe and Read, 2005; Clancey et al, 2011).

In the United States, CPTED practitioners has been expanded the approach to cover 'social' or 'community' dimensions. Second Generation CPTED (Saville and Cleveland, 1997)—as it 
is known in the US_aims to build small-scale neighbourhoods and to foster healthy communities that support residents through, for instance, community events and provision of meeting places. Second Generation CPTED has also been proposed to help tackle domestic abuse, a crime that is usually perpetrated against women and within the home (DeKeseredy et al, 2005, 2009).

In practice, CPTED can take a variety of forms, since it may be integrated with other strategies and tailored to the particular needs of specific stakeholders groups. In Vienna, CPTED has been implemented within gender mainstreaming and urban planning to improve women's feelings of safety in the city/ (Stummvoll, 2004). In the UK, design guidance is available to on how to integrate crime within the design process to reduce vulnerability of a design to crime (Design Council, 2011; Davey and Wootton, 2014; Wootton and Davey, 2012). CPTED is also being considered within efforts to promote sustainability and digital technologies (UNICRI, 2011).

The term CP-UDP has been adopted by COST Action TU1203 to better engage practitioners in the urban design and planning disciplines. Unless referring to an approach explicitly relating to CPTED, the authors refer to CP-UDP in this article.

\subsection{Case Study Methodology and review}

Through COST Action TU1203, the authors, together with other experts, were able to learn how CP-UDP is being delivered in different EU contexts. In each city, COST members listened to presentations from practitioners and academics, and visited development and regeneration projects. Members also shared relevant materials-including published articles, project reports and data. To help capture and communicate their knowledge, information from each visit was presented in the form of a case study. To improve their quality, COST members conducted further desk research, interviews with practitioners and site visits. As leaders of COST Working Group 3 on case studies, the authors developed a standard protocol to provide structure for cases and enable comparison. The protocol asked researchers to provide a crime prevention case study, outlining aims, development process, method of delivery, impact and key learning points. The context for the case was described using a crime prevention timeline, and detailing relevant national, regional and city/municipal context factors. The implications of the case for future practice where considered in relation to emerging issues, tensions and opportunities for development.

Different crime prevention approaches were observed and written up during COST TU1203-from European-wide procedures, through national schemes to local strategies and single development projects. This paper utilises findings from case studies and reports into CP-UDP strategies-as opposed to single development projects (reported under practical cases). In this paper, the authors present four innovative strategies to integrate crime prevention into urban design, planning and management practice. The four strategies are recognised by experts in the field as pioneering. Collectively they illustrate the breadth of approaches adopted-from the European-wide to the local:

1. A standardised approach to CPTED delivery across Europe - European Standard for Urban Design and Planning 
2. A national scheme to embed safety and security criteria into urban development Dutch Police Label for Safe and Secure Housing that was inspired by the UK's Secured By Design scheme and first piloted in North Holland.

3. An police architectural liaison service redesigned to better meet the needs of architects, developers and planners in Greater Manchester (UK) - Greater Manchester Police Design for Security service

4. A safety partnership in the German federal state of Lower Saxony that is at the forefront of efforts to integrate safety and security into urban planning, design and management.

\subsection{European Standard for Urban Design and Planning}

The European Standard for Urban Design and Planning is ambitious in both its aim and scope. The ambition is to ensure a standard, evidence-based approach to addressing problems of crime and insecurity in urban environments across Europe. The approach and content of the standard was developed between 1995 and 2007 by experts in crime prevention, architecture and planning from across Europe. This hardy group collaborated in the development of the official CEN European standardisation documents that would be distributed by each national standardisation institute. The overall 'umbrella standard' is officially titled CEN/TR 14383-2 for Urban Design and Planning (Grönlund, et al, 2014).

A standard (in French: Norme; and in German: Norm) is defined by the European Committee for Standardisation (Comité Europeen de Normalisation - CEN2) as:

"... a technical document designed to be used as a rule, guideline or definition. It is a consensus-built, repeatable way of doing something."

(Grönlund, et al, 2014, p.3)

Standards define the characteristics of products, processes or services, and in many cases determine safety requirements for the design and construction of products.

Product standards specify security technologies and/or performance requirements for the industry, and support clients and customers in their efforts to 'target harden' buildings and environments. Target hardening is where security or design features are used to deny potential offenders access to items they might consider of value. However, the European Standard for Urban Design and Planning goes beyond such measures, drawing on the theory that the opportunity for committing a crime is not only contingent upon technical target hardening, but also depends on the social, temporal and physical context.

The European Standard is innovative in its application of a scientific management approach to the context of urban design and planning for improved safety and security, derived from existing international standards on quality management (ISO 9000 series). The 2000 version of ISO 9000 represented a radical change in thinking by focusing on the concept of 'process management'. That is, the monitoring and optimisation of an organisation's goals, tasks and activities - as opposed to inspection of a final product.

The ultimate goal and desired outcome of applying the European Standard for Urban Design and Planning is the successful development of "a good environmental management system" (Grönlund, et al, 2014, p. 7). This can be achieved by key stakeholders responsible for the 
urban environment (including local authorities, businesses and public services) following a straightforward 7-step process (ibid):

1. Crime review or crime assessment of the area or the urban plan

2. Definition of objective or requirements

3. Plan proposed project

4. Decision about plan/amendments by Responsible Body

5. Action and implementation of plan/amendments

6. Audit

7. Corrective action (if necessary).

In its Annex, the European Standard details approaches and tools to support multi-agency working, understand the urban context and identify problems related to safety and security. Importantly, the tools do not attempt to prescribe solutions (which might be applicable only to particular contexts), but rather support stakeholders in their efforts to generate and develop solutions appropriate to their specific context. Thus, the 7 step process and accompanying tools were designed to be applicable irrespective of local culture, urban situation, design concept and/or planning philosophy, and to be in fact "universally applicable" (Grönlund, et al, 2014, p. 39).

\section{Impact of the European standard - the positive}

Importantly, the process of developing a European Standard appeared to result in a movement away from a 'checklist approach' to crime prevention amongst participants, towards what has been identified by the Chair as a "counselling approach" (Van Soomeren and Woldendorp, 1997).

Checklists may serve well at summarising 'good' and 'bad' design features, as judged from a crime preventive and feeling of security perspective. However, checklists tend to be resented by architects and urban designers, concerned that such simplistic guidance constrains their creativity and may undermine the achievement of other design priorities. The design process centres around generating a creative response to a brief that embodies a broad range of requirements (Wootton and Davey, 2012). Crime prevention checklists tend not to communicate underlying requirements that might be met and integrated creatively within a design solution, but rather attempt to impose rigid 'micro solutions' that have the potential to compromise an otherwise satisfying design (ibid).

In contrast, in the counselling approach, crime prevention advisors with a strong theoretical and practical expertise in planning, architecture and urban design work together within the design team to support appropriate design decision-making (Grönlund, et al, 2014). The aim is to enable the design team to consider the 'dark side' of their design proposal-the feelings of insecurity, opportunities for misuse and offending behaviour it might engender-and to support efforts to generate innovative solutions that prevent problems arising in the first place, without undermining the achievement of other priorities (Design Council, 2011; Wootton and Davey, 2012).

\section{Impact of the European standard - the disappointing}

The Standard was published by CEN as the European Pre-Norm ENV14383-2 in 2003, and some changes were made after this date.Disappointingly, in May 2005, delegates abstained 
from supporting the 'Pre-Norm' in becoming an EN standard, instead advocating it become a Technical Report (TR).

Notably, a Technical Report does not oblige EU countries to amend their national standards where they come into conflict with it (Grönlund et al, 2014, p. 18). Thus, the demotion from a ENV to a TR meant that the legislative mechanism for addressing safety and security in a standard way across Europe was removed. In effect, the 'umbrella standard' CEN/TR 143832 on Urban Design and Planning has become a general set of guidelines validated by experts from across Europe. While a useful document, without it being a European Standard there is no way to ensure that its valuable approach to safety and security are embedded within urban design, planning and management practice across Europe.

\subsection{National schemes to embed safety and security into urban development [AK4]}

The Netherlands was at the forefront of efforts to establish a European Standard in urban design and planning, with Paul van Soomeren (DSP-groep, NL) chairing the Working Group. The decision to transform the Pre-Standard into a Technical Report was understandably disappointing for those involved in its long development. Nevertheless, in 1994 a Dutch accreditation scheme for the development and construction of new residential estates was piloted in one police district, and then rolled out nationwide in 1996. The scheme was Police Label for Safe and Secure Housing (Politiekeurmerk Veilig Wonen $\left.{ }^{\circledR}\right)$. The Dutch also supported a more general scheme operational since the 1990s-the 'Safety Effect Report'designed to provide deeper insight into the safety risks in spatial and building plans (Grönlund, et al, 2014).

In the Dutch Police Label, the focus is on safety and security not merely related to individual dwellings, but in the wider context of the new estate environment. The design manuals were written in a form that could be easily understood by urban planners, landscape architects and architects, and updated to allow designers greater flexibility and scope for creative interpretation. In addition to using language consistent with architectural design, the Dutch Police Label draws heavily on 'pattern language' developed by Christopher Alexander et al (1977) — a theory familiar to planning practitioners (Jongejan and Woldendorp, 2013).

In the Netherlands, implementation of the Police Label is voluntary, with clients free to choose whether or not to adopt the Police Label for their development (Jongejan and Woldendorp, 2013). Until 2005, specially trained "Building Plan Advisors" (ibid p.34) within the police helped the client and design team to incorporate the Police Label into their design.

In 2005, the Police Label Secure Housing scheme was considered sufficiently developed for direct delivery by the Dutch local authorities. The 415 municipalities responsible for planning and building were expected to employ Building Plan Advisors throughout the design and management of both housing and public space-which is proving something of a "challenge" (Jongejan and Woldendorp, 2013, p.47). Ownership of the Label was transferred from the Dutch Ministry of the Interior to the Dutch Centre of Crime Prevention and Safety (CCV) (ibid).

\section{The impact - secure dwellings}


The results of the Dutch Police Label Secure Housing scheme have been impressive. The risk of a dwelling being burgled has dropped by 95 per cent in new build estates and 80 per in existing environments that achieved accreditation (Nauta, 2004, cited in Jongejan and Woldendorp, 2013). Crime is reduced by applying CPTED principles and ensuring physical barriers to accessing the dwelling can withstand criminal attack for at least three minutes. This is a period of time considered sufficient to deter offenders who wish to avoid being noticed by residents or passers by. The development of attack testing has encouraged the use of building materials resistant to burglary. The Police Label also incorporates other safety requirements, such as the inclusion of a smoke detector (Jongejan and Woldendorp, 2013). By 2011, it was reported that approximately 600,000 dwellings have been awarded a Police Label Secure Housing certificate (Politiekeurmerk Veilig Wonen, 2011, cited in Jongejan and Woldendorp, 2013). However, in-depth research is required to understand the challenges and impact resulting from the change in ownership and delivery structure.

\subsection{Greater Manchester embeds crime prevention within design and planning}

At the turn of the millennium, the UK police accreditation scheme Secured by Design (SBD) was being delivered by police forces across the country. Using this scheme, police Architectural Liaison Officers (in some forces called Crime Prevention Design Advisors) were assessing building designs being submitted for SBD accreditation and/or for planning approval. However, there are significant differences between police forces in terms of approach, resource allocation and integration within planning processes (Wootton et al, 2009). Greater Manchester Police's (GMP's) 'Design for Security' consultancy service has emerged as an innovative service design, considered a potential role model for other police forces in the UK and internationally (Davey and Wootton, 2014, 2015, 2016; Wootton et al, 2009).

Design for Security and the Greater Manchester local authorities work together to integrate crime prevention within the early stage of the design development process. The local planning authority make crime prevention a requirement or 'condition' for granting planning permission and GMP employs Design for Security Consultants to help designers and developers fulfil this requirement (Davey \& Wootton, 2015, 2016). It is worth briefly outlining how designers operate and apply their skills. A project is usually set up by the client and an urban design team or architect employed. During the early stages of the development process, the architect creatively explores ideas and develops a concept to fulfil needs and requirements of users and stakeholders. It is at this early stage when crime issues need to be considered and the architect provided with relevant information-reports of crime risk, Modus Operandi of offenders and good practice principles. Urban designers should also be supported in their efforts to understand emotions, feelings and behaviours related to crime and insecurity. Reducing vulnerability to crime will be just one of a range of desirable objectives to be considered and the costs and benefits of crime prevention solutions will clearly need to be calculated (Wootton and Davey, 2012) .

In Greater Manchester, local authorities have made it a condition for applicants to submit a 'Crime Impact Statement' with their application for planning approval. The Crime Impact Statement contains contextual information about crime risk, as well as a review of the vulnerability of the proposed design. GMP's Design for Security Consultants review all major building development projects submitted for planning approval. This has encouraged 
architects and developers to consult Design for Security Consultants at an early stage of the design process, incorporating their advice into the final design. Early stage consultation benefits architects and developers by allowing advice to more easily be incorporated into the design (Davey and Wootton, 2015).

Importantly, GMP's Design for Security Consultants are all civilian staff-not police officersand all have a background in the development industry. As a result, the Consultant 'speaks the same language' and is more able to act as a 'critical friend' to the architect, highlighting potential vulnerabilities associated with a design proposal and outlining principles for improving safety and security. GMP's Design for Security Consultants are equipped to respond to the demands and requirements of the planning process in Greater Manchester. They are, for example, entirely dedicated to the role and able to review designs submitted for planning permission within a specified time-currently 21 days. Unlike police Architectural Liaison Officers in other forces, the Consultants are not diverted from this important role by the need to perform other police duties (Wootton and Davey, 2016).

\section{Future for GMP and UK police forces}

GMP is able to charge a consultancy fee for the service they provide, thereby covering the cost to the police of its delivery. As an income-generating service, Design for Security has allowed GMP to retain its crime prevention capability in a time of austerity. This is not the case in other police forces in England and Wales where significant cuts in public spending since 2010 have reduced the number of police Architectural Liaison Officers (Davey and Wootton, 2015).

The Design for Security approach—or 'Manchester Model' as it became known—was proposed as a model of good practice for adoption across England and Wales (Wootton et al, 2009; www.npcps.org). Unfortunately, proposals outlined in 2009 for a National Police Crime Prevention Service (NPCPS) have yet to be taken forward (ibid).

\subsection{A partnership approach in Lower Saxony}

The desirability of adopting a European Standard is not universally accepted. Germany, for example, chose not to participate in the development of the European Standard for Urban Design and Planning (Grönlund, et al, 2014; PLuS project, 2012). Federal states in Germany tend to develop their own approach to safety and security suited to their particular context and strengths. With regard to integrating crime prevention into urban design and planning, the federal state of Lower Saxony is a leader in the field.

The Landeskriminalamt (LKA) in Lower Saxony drives efforts to integrate crime prevention into policing, planning and housing policies. .

In 2003, the 'Security Partnership in Urban Development in Lower Saxony'

(Sicherheitspartnerschaft im Städtebau in Niedersachsen) was established. The Partnership brings together around 30 local planning authorities, police and housing providers, who meet on a regular basis to develop and review strategic urban plans and discuss how to improve safety and security within future and existing developments (Schubert, 2012).

To integrate crime prevention into the design and management of the environment, a quality audit scheme for secure living has been established. (further information available from: http://www.sipa-niedersachsen.de/). In addition, the LKA in Lower Saxony employs two 
civilians with a background in the development industry to provide free advice to architects during the design and development process.

\subsection{Mapping European CP-UDP approaches}

In 2008, the LKA established a research project to develop crime prevention measures that might be transferrable across Europe-Planning Urban Security (PLuS). The LKA in Lower Saxony were resistant to the adoption of a European Standard (Davey and Wootton, 2015; PLuS Reports, 2012), but were nevertheless interested in learning from leaders in the fieldincluding GMP's Design for Security service and a gender mainstreaming approach in Vienna (Austria) focused on improving women's feelings of safety and security (Stummvoll, 2004). In an attempt to overcome obstacles to understanding crime prevention strategies within different linguistic and cultural contexts, the authors worked with project partners to develop a conceptual framework that allows different approaches to CP-UDP to be understood and categorised-the 'Crime Prevention Capability Maturity Model'.

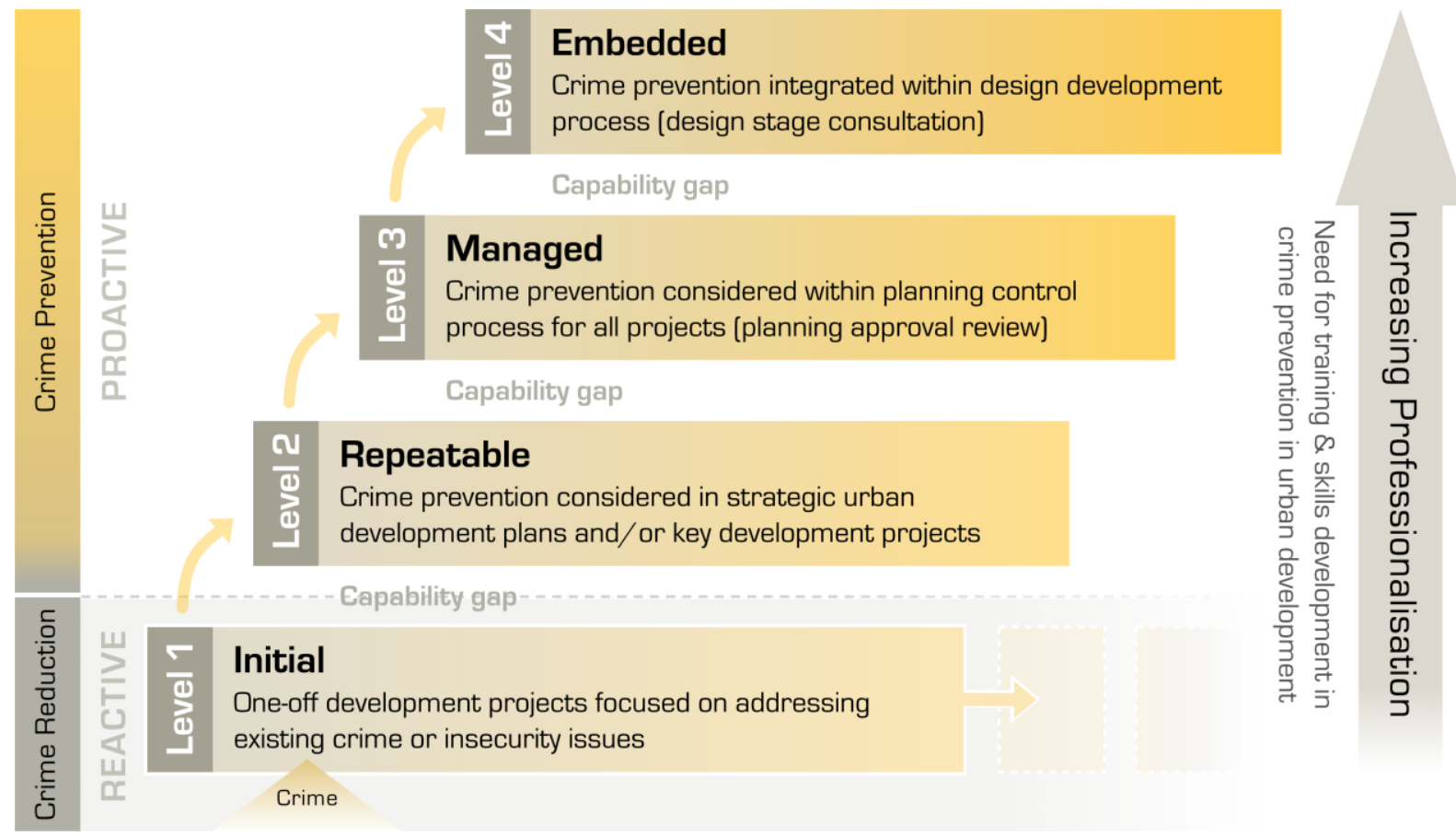

Figure 1. Crime Prevention Capability Maturity Model - The four maturity levels of CP-UDP

The Crime Prevention Capability Maturity Model (CPCMM) details four levels of maturity, as follows:

1. Initial - One-off development projects focused on addressing existing crime or insecurity issues

2. Repeatable - Crime prevention considered in strategic urban development plans and/or key development projects

3. Managed - Crime prevention considered within planning control process for all projects (planning approval review)

4. Embedded-Crime prevention integrated within design development process (design stage consultation). 
The model illustrates how groups of stakeholders can move from an ad hoc, project-oriented manner of CP-UDP delivery to more strategic approach (Davey and Wootton, 2014). The model recognises that there are benefits to enabling design professionals to consider safety and security requirements at an early stage of the design process, when design solutions are yet to be finalised. The model suggests that crime prevention might be embedded into professional urban design practice by integrating it into planning processes and continuous professional development. The long-term sustainability of CP-UDP will only be achieved through its professionalisation, when urban designers, architects and planners consider crime prevention (reducing the of risk of victimisation for users) as an important part of their professional role and responsibility.

Importantly, the model distinguishes between efforts to address existing crime problems (crime reduction) and those to prevent the emergence of problems in the first place (crime prevention). It seeks to clarify the step change from reactive to proactive approaches-from crime reduction to crime prevention-and to classify the increasing capability maturity required for CP-UDP to become integrated within professional practice. Between each level of the model is the 'capability gap' that must be addressed for practice to improve. It is in overcoming these 'capability gaps' that the support of professional bodies and central government may be required.

In relation to some features, Lower Saxony has clearly moved from a participation in individual projects to an established managed process-indicative of level 2 . The planning process makes all developers and architects in the federal state aware of the need to consider crime prevention, as part of the quality of life agenda. Developers and architects are expected to act on this requirement. Moving to level 3 more fully would require mechanisms for checking and ensuring compliance, but it is not clear that increased capability around planning control is necessary and/or desirable within the German context (Davey and Wootton, 2014).

The LKA in Lower Saxony has chosen to establish a managed process underpinned by indepth research that is better able to address feelings of insecurity amongst residents in Lower Saxony. At the time of writing, the LKA is leading a major research project involving the analysis of data from some 20,000 surveys completed by residents in Lower Saxony and detailed studies of environmental factors that foster feelings of insecurity (http://www.transitonline.info/home/partner.html).

\subsection{Conclusion}

Methods and procedures developed by the European Committee for Standardization (CEN) Working Group on "Crime Prevention through Urban Planning and Building Design" might be considered pioneering, in their adoption of a process-oriented approach. COST Action TU1203 provided a valuable opportunity to identify and discuss lessons learned from the development of the European Standard. Cooperative effort focused on a clear goal (in this case, creating an EU Standard for Urban Design and Planning), an acceptance of the need to make trade-offs, and a willingness to develop strategies that transcended disciplinary, cultural and contextual differences were all integral to the process of development. Importantly, a by-product of this collaborative development process was a cohort of practitioners and academics united in their interest to expand the understanding of CP-UDP 
theory and practice. This cohort of experts has been able to continue their collaboration through COST Action TU1203-established by Professor Clara Cardia and being taken forward under the capable leadership of her close colleague Dr Umberto Nicolini.

Findings from the Netherlands, UK and Germany in particular show that implementation is best achieved at a local level using methods and procedures tailored to the specific context. However, there is a need for in-depth research to evaluate and map design and planning practices-especially in countries where significant changes in these practices are underway. For example, national legislation in France is resulting in the impact of crime becoming an important consideration in the design of major building developments. Research also needs to assess the impact on crime prevention delivery of the financial crisis and the resulting austerity agenda that has emerged in countries such as England and Wales (Davey and Wootton, 2015).

Applied research on CP-UDP appears under threat, however, due to a shift in political focus to other challenges. For example, in the security field, funding opportunities at a European level are increasingly focused on counter terrorism, crisis and disaster management (see EU Horizon2020 Secure Societies programme). In addition, European security funding is increasingly technocentric and geared towards the development of 'technology solutions'.

Crime prevention practitioners and academics benefit greatly from participation in focused, multi-agency collaborations that, importantly, facilitate access to real-world practice and the generation of valuable insight. This includes: visits to urban developments; discussions with local stakeholders responsible for delivery 'on the ground'; and structured and sustained exploration of innovations and challenges.

The authors hope that design-led crime prevention will become integrated within the professional practice of urban designers, architects and planners-who will come to accept crime prevention as part of their professional role and responsibility. The process of 'professionalising' crime prevention is at the heart of the Crime Prevention Capability Maturity Model and is being actively pursued in some some parts of the EU (Davey and Wootton, 2014). To achieve this requires a focus on capability improvement that must be supported at least in part by central government and relevant professional bodies.

The ambition of members of COST Action TU1203 is that the political will be found to continue this journey: that the achievements of more than a quarter century of development in CP-UDP can be secured, and the resource found to continue forward.

\section{References}

Alexander, C., Ishikawa, S. and Silverstein, M. (1977) A Pattern Language: Towns, Buildings, Construction. New York: Oxford University Press.

Clancey, G., Fisher, D. and Lee, M. (2011) "Do Crime Risk Assessment Reports Measure Crime Risks?", Current Issues in Criminal Justice, Vol. 23, No. 2, pp. 235 - 254. Available at: http://www.austlii.edu.au/au/journals/CICrimJust/2011/28.pdf

Clarke, R. (1999) "Hot Products: understanding, anticipating and reducing demand for stolen goods". Police Research Series Paper 112. Home Office Policing and Reducing Crime Unit 
Research, Development and Statistics Directorate. Available at:

http://www.popcenter.org/tools/risky_facilities/PDFs/Clarke_1999.pdf

Cohen, L. E. and Felson, M. (1979). "Social Change and Crime Rate Trends: A Routine Activity Approach”. American Sociological Review, Vol. 44, pp. 588-608. Available from: http://www.personal.psu.edu/exs44/597b-Comm\&Crime/Cohen_FelsonRoutine-Activities.pdf

Cozens, P. and Love, T. (2015), "A Review and Current Status of Crime Prevention through Environmental Design (CPTED)", Journal of Planning Literature., pp. 1-20. first published online before print on August 9.

Davey, C.L. and Wootton, A. B. (2016) Manchester. Metropolitan Area of Greater Manchester. COST Case Study.

Davey, C.L. \& Wootton, A.B. (2015) "Design for Security" in Greater Manchester:

Entwicklung eines Dienstes zur Integration von Kriminalitätsprävention in Urban Design und Stadtplanung" in Sicherheit in der Stadt. Rahmenbedingungen, Praxisbeispiele , Internationale Erfahrungen. (Ed) Floeting, H. Deutsches Institut für Urbanistik (DIFU): Berlin, Germany.

Davey, C.L. and Wootton, A.B. (2014) "The Crime Prevention Capability Maturity Model". International Perspectives of Crime Prevention 6. Contributions from the 7th Annual International Forum 2013 within the German Congress on Crime Prevention. Forum Verlag Godesberg Gmbh, Mönchengladbach, Germany. Available from: http://www.gcocp.org/kriminalpraevention/Module/Buecher/ISBN-978-3-942865-29-6.pdf

DeKeseredy, W.S., Donnermeyerb, J.F. and Schwartz, M.D. (2009) "Toward a gendered Second Generation CPTED for preventing woman abuse in rural communities". Security Journal, Vol. 22, 178-189.

DeKeseredy, W. S., Shahid, A., Renzetti, C.M. and Schwartz, M. D. (2005) "Reducing Private Violence against Women in Public Housing: Can Second Generation CPTED Make a Difference?" CRVAW Faculty Journal Articles. Paper 300. http://uknowledge.uky.edu/crvaw_facpub/300

Design Council (2011) Designing Out Crime. A Designer's guide. Design Council: London, UK. Original research conducted by the Design Against Crime Solution Centre, University of Salford.

Ekblom, P. (2001). "The Conjunction of Criminal Opportunity: A Framework for Crime Reduction Toolkits." Accessed January 31, 2007 from Crime Reduction website: http://www.crimereduction.gov.uk/learningzone/ccofull.doc.

Ekblom, P. (2009). "Redesigning the Language and Concepts of Crime Prevention through Environmental Design. Reconstructing CPTED." October 30, 2010. Accessed February 7, 2012.http://reconstructcpted.wordpress.com/publications-and-otherpapers/. 
Ekblom, P. (2011). "Deconstructing CPTED and Reconstructing It for Practice, Knowledge Management and Research." European Journal on Criminal Policy and Research, Vol. 17, pp. 7-28.

Farrell, G. (2013) "Five Tests for a Theory of the Crime Drop". Crime Science: An Interdisciplinary Journal. Vol. 2, no. 5, pp. 1-8. Available at:

http://crimesciencejournal.springeropen.com/articles/10.1186/2193-7680-2-5

Grönlund, B, Korthals Altes, H. J., van Sommeren, P. and Stümmvoll, G. (2014) "Review of CEN 14383. The death and life of great European standards and manuals. COST Action TU1203 Crime Prevention Through Urban Design and Planning, Working Group 2, Available from: http://costtu1203.eu/downloads/cost-tu1203s-results/

Jacobs, J. (1961). The Death and Life of Great American Cities. London, UK: Jonathon Cope.

Jeffery, C. (1971) Crime Prevention through Environmental Design. Beverly Hills, CA: Sage. Jongejan, A. and Woldendorp T. (2013) "A Successful CPTED Approach: The Dutch 'Police Label Secure Housing"' Built Environment, Vol. 39, no. 1. pp. 31-48.

Nauta, O. (2004) "De effectiviteit van het Politiekeurmerk. Veilig Wonen". Amsterdam: DSP_ groep. Politie Keurmerk Veilig Wonen (2011) Mailing PKVW-certificaten gemeenten, cited in Jongejan, A. and Woldendorp T. (2013) (abid).

Newman, O. (1972) Defensible Space: Crime Prevention through Urban Design. New York: Macmillan.

PLuS Reports (2012) Planning Urban Security. Reports available from LKA Niedersachen website (accessed September 2015): http://www. Ika.polizei-

nds.de/praevention/vorbeugung themen und tipps/staedtebau/staedtebau-152.html

Saville, G. and Cleveland, G. (1997) 2nd Generation CPTED. "An Antidote to the Social Y2K Virus of Urban Design". Paper presented at the 2nd Annual International CPTED

Conference, Orlando, December. Download from: http://www.veilig-ontwerpbeheer.nl/publicaties/2nd-generation-cpted-an-antidote-to-the-social-y2k-virus-of-urbandesign

Shaftoe, H. and Read, T. (2005) "Planning out crime: the appliance of science or an act of faith?" in Tilley, N. (ed) Handbook of Crime Prevention and Community Safety, Willan Publishing, pp. 248.

Schubert, H. (2016) "Urban Crime Prevention - Broadening of Perspectives". Journal of Place Management, vol. Issue, pp. X.

Schubert, H. (2012) "Die Sicherheitspartnerschaft im Städtebau und das Qualitätssiegel für sicheres Wohnen in Niedersachsen. Sicher leben in Stadt und Land". Ausgewählte Beiträge 
des 17. Deutschen Präventionstages 2012, Forum Verlag, Godesberg 2013: 303-327, Hg.: Erich Marks, Wiebke Steffen (Hrsg.)

Schneider, R., and T. Kitchen. (2002). Planning for Crime Prevention: A Transatlantic Perspective. London, UK: Routledge

Stummvoll, G. P. (2013) "Governance through Norms and Standards: The Normative Force Behind Design-led Crime Prevention”. Criminology and Criminal Justice, 0 (0) 1- 20.

Stummvoll, G.P. (2004) "Design Against Crime in Vienna: A Feminist Approach". Crime Prevention and Community Safety: An International Journal, Vol. 6, no. 4, pp. 71-82.

UNICRI (2014) “Improving Urban Security Through Green Environmental Design: New Energy for Urban Security". United Nations Interregional Crime and Justice Research Institute

http://www.unicri.it/news/files/2011-04-01_110414_CRA_Urban_Security_sm.pdf

van Dijk, J. (2013) "The International Crime Victims Survey". Criminology in Europe. Newsletter of the European Society of Criminology, 2013, Vol. 11. Available from: www.esceurocrim.org

van Dijk, j, Tseloni, A. and Farrell, G. (2012) "Introduction”, in The International Crime Drop. New Directions in Research. Crime Prevention and Security Management. (eds) Jan van

Dijk, Andromachi Tseloni and Graham Farrell, Palgrave Macmillan, United States.

van Soomeren P. and Woldendorp T. (1997) "CPTED in the Netherlands". EU Conference on 'Crime Prevention: towards a European Level' in Noordwijk, the Netherlands. Amsterdam, DSP-groep. (http://www.veilig-ontwerp-beheer.nl/publicaties/cpted-in-the-netherlands/).

Wootton, A.B., Marselle, M., Davey, C.L., Armitage, R. and Monchuk, L. (2009) National Police Crime Prevention Service. Implementation Planning Research Project. Design Against Crime Solution Centre: Salford, UK. Available from: www.npcps.org

Wootton, A.B. \& Davey, C.L. (2012) "Embedding Crime Prevention within Design", in Ekblom, P. (Guest Ed), Design Against Crime. Crime Proofing Everyday Products. Crime Prevention Series, Vol. 27, Ronald.V. Clarke, (Series Editor).

https://www.rienner.com/title/Design Against Crime Crime Proofing Everyday Products 